\title{
Desain Materi Bangun Datar Menggunakan Origami Berkonteks Tangram di SD Kelas II
}

\author{
Lisnani \\ Program Studi PGSD, Universitas Katolik Musi Charitas \\ e-mail: Lisnanipcmtk@yahoo.com
}

\begin{abstract}
The study aims to improve the ability of mathematical communication in recognizing, grouping various types of flat wake. The subjects of the study were elementary school students Class IIA in SD Negeri 43 Palembang amounted to 27 people. Data collection is done through observation sheets, interviews, tests, documentation, and field notes. The research method used is a research design consisting of three stages: First stage, preliminary design/ preparing for the experiment; The second stage, design experiment consisting of pilot and teaching experiment. The third stage, retrospective analysis. This study develops a series of activities and strategies that learners do on a flat wake material. The results of this study in the form of learning trajectory (learning path) in each activity are: First activity, learners recognize various shapes and characteristics of wake up flat with conventional way. Then, on the second activity, learners can recognize the types and characteristics of the wake up trained by using the model match a make. Furthermore, the third activity, enhances its mathematical communication ability by using origami tangram context.
\end{abstract}

Keywords : Design Research, Mathematical Communication, Make a Match, Origami

\section{PENDAHULUAN}

Dalam kehidupan sehari-hari kita beberapa kegiatan berhubungan dengan matematika. Mulai dari menghitung, mengukur, membaca waktu, melihat berbagai bangun datar dan bangun ruang, membuat grafik/tabel dan lain sebagainya. Hal ini membuktikan bahwa matematika mempunyai peranan penting di kehidupan manusia. Sejak duduk di bangku sekolah dasar (SD), pelajaran matematika bertujuan untuk melatih kemampuan berpikir sistematis (teratur), logis (masuk akal), kritis (banyak bertanya, tidak lekas percaya), kreatif (berdaya cipta), dan konsisten (ajek, sesuai aturan).

Salah satu materi pelajaran matematika yang dipelajari di bangku SD adalah bangun datar. Menurut Kemendikbud (2013), pada Kurikulum 2013 peserta didik sudah mempelajari bangun datar sejak peserta didik duduk di kelas II SD. Peserta didik mulai diperkenalkan dengan berbagai bentuk bangun datar seperti persegi, persegi panjang, jajar genjang, trapesium, belah ketupat, layang, dan segitiga. Pembelajaran tentang pengenalan berbagai bentuk bangun datar dimulai dengan mempelajari pengertian, bentuk, dan ciri-ciri dari bangun datar. Berdasarkan pengalaman peneliti yang pernah melakukan penelitian dan observasi di beberapa SD, bangun datar merupakan salah satu materi yang sulit dipahami peserta didik. Sebagian besar peserta didik mengalami kesulitan dalam mengenal, mendeskripsikan ciri-ciri, menghitung luas dan keliling bangun datar. Deskripsi yang dimaksud adalah secara verbal (kata-kata) dalam bentuk komunikasi dan sulit memahami materi. Padahal materi bangun datar akan terus dijumpai oleh peserta didik dari sejak SD sampai ke SMA, yang dikenal dengan nama geometri. Memandang pentingnya materi bangun datar untuk dipahami oleh pesrta didik, kemudian mampu mengkomunikasikan pemahaman mereka, baik secara lisan maupun tulisan, maka diperlukan suatu cara untuk 
mengatasi kesulitan peserta didik dalam mengkomunikasikan pemahaman mengenai bangun datar ini. Kesulitan matematika harus diatasi sedini mungkin, kalau tidak akan menghadapi banyak masalah pada setiap jenjang pendidikan, matematika selalu diperlukan termasuk dalam kehidupan sehari-hari (Sundayana, 2015: 25-26).

Ada banyak faktor penyebab peserta didik sulit memahami materi bangun datar, diantara adalah model pembelajaran yang digunakan guru kurang variatif, keterbatasan media pembelajaran baik berupa alat peraga maupun permainan, cara berpikir peserta didik dari hal-hal konkret menuju abstrak sedangkan kebanyakan konsep dalam matematika bersifat abstrak. Hal ini sesuai dengan tingkat perkembangan intelektual anak SD yang masih dalam tahap operasi konkret, peserta didik SD harus dibantu untuk menerima konsep-konsep matematika yang abstrak melalui benda-benda konkret. Salah satu media yang dapat dijadikan sumber belajar materi bangun datar ialah origami berkonteks tangram. Kertas origami yang berwarna-warni digunting membentuk tan, yaitu bagian (potongan) tangram yang berbentuk bangun datar, yaitu 5 buah segitiga, 1 jajar genjang dan 1 persegi (lihat gambar 1). Tujuan permainan tangram itu sendiri adalah menyusun 'tan' tersebut menjadi suatu bentuk, atau mengikuti pola bentuk yang telah disediakan.

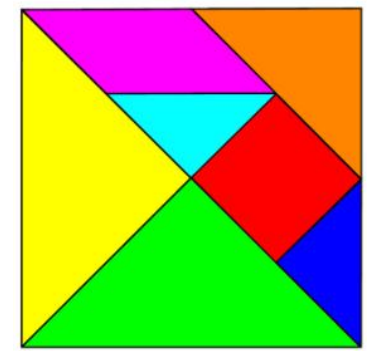

Gambar 1. Tangram

Menurut Nurdin (2016), tangram merupakan suatu media yang dapat digunakan untuk memfasilitasi kemampuan geometri siswa. Tangram menjadikan siswa bersemangat dan aktif dalam pembelajaran. Hal ini sesuai dengan pendapat para ahli bahwa tangram bermanfaat bagi anak-anak dalam berbagai hal, di antaranya (Althouse 1997; Krieger 1991; National Council of Teacher's Mathematics 2003):

1. Mengembangkan rasa suka terhadap geometri

2. Mampu membedakan berbagai bentuk

3. Mengembangkan perasaan intuitif terhadap bentuk-bentuk dan relasi-relasi geometri

4. Mengembangkan kemampuan rotasi spasial

5. Mengembangkan kemampuan pemakaian kata-kata yang tepat untuk memanipulasi bentuk (misalnya ' membalik', 'memutar', 'menggeser')

6. Mempelajari apa artinya 'kongruen' (bentuk yang sama dan sebangun)

Tangram yang dibuat dari kertas origami dapat dijadikan sebagai media pembelajaran yang dapat membantu peserta didik dalam memahami materi bidang datar. Setelah memahami bidang datar, peserta didik dapat dilatih untuk mengkomunikasikan ide-ide matematisnya (lisan maupun tulisan), baik kepada peserta didik ataupun kepada guru dengan model atau strategi pembelajaran yang sesuai.

Model pembelajaran make and match adalah sistem pembelajaran yang mengutamakan penanaman kemampuan sosial terutama kemampuan bekerja sama, kemampuan berinteraksi disamping kemampuan berpikir cepat melalui permainan mencari pasangan dengan dibantu kartu (Wahab, 2007: 59). Penerapan metode ini dimulai dari teknik yaitu peserta didik diminta untuk mencari pasangan kartu yang merupakan jawaban/soal sebelum batas waktunya, peserta didik yang dapat mencocokkan kartunya diberi poin. Menurut Sani dan Kurniasih (2015), model pembelajaran make a match atau mencari pasangan dikembangkan oleh Lorna Curan, dimana pada model pembelajaran ini peserta didik diajak mencari pasangan sambil belajar mengenai suatu konsep atau topik dalam suasana yang menyenangkan. Keistimewaan model make a match ini 
adalah peserta didik berusaha memasangkan kartu bangun datar dengan ciri dan sifatnya dengan tepat sehingga peserta didik dilatih untuk mengindentifikasi masalah, belajar dengan aktif karena guru hanya berperan sebagai pembimbing, meningkatkan antusiasme dalam proses pembelajaran, dengan penyelesaian soal maka otak peserta didik akan bekerja lebih baik, dan terjadi interaksi antar kelompok dan antar peserta didik dalam membahas soal dan jawaban yang dihadapi.

Model make a macth ini membutuhkan waktu lebih untuk permainan mencocokkan kartu, membahasnya satu persatu dan menarik kesimpulan. Persiapan yang perlu dilaksanakan untuk pembelajaran make and match harus cukup karena harus membuat soal atau jawaban yang berbeda dan ditempel di kartu sebanyak jumlah peserta didik. Penerapan model pembelajaran make a match seperti pada gambar 2 .

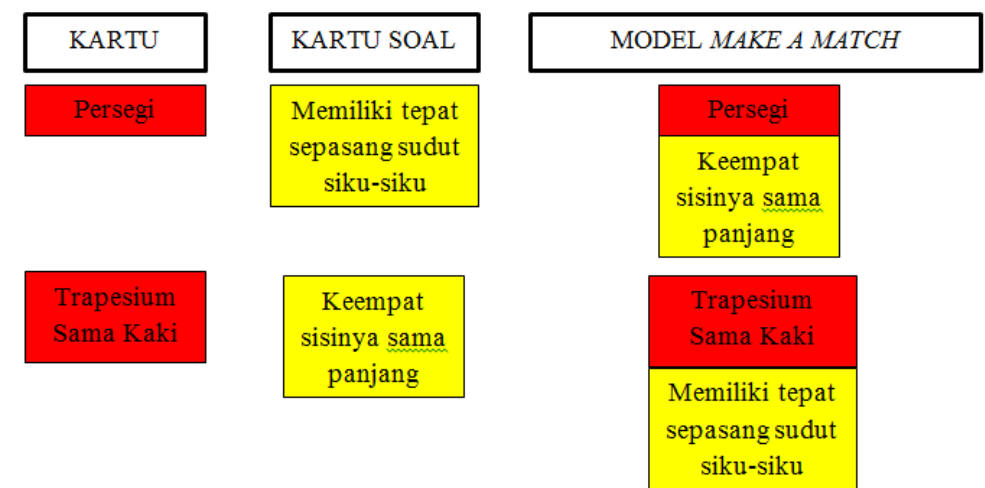

Gambar 2. Model Pembelajaran Make A Match

Setelah berhasil mencocokkan kartu soal dan jawaban, peseta didik dilatih untuk mengkomunikasikannya di depan kelas. Melalui pembelajaran make a match, peserta didik dilatih untuk mengindentifikasi masalah, belajar dengan aktif dan mengkomunikasikan ide-ide antar peserta didik maupun kepada guru. Penggunakan origami yang dibentuk menjadi tangram yang berwarna-warni akan menarik peserta didik untuk belajar dengan menyenangkan. Pada akhirnya, pembelajaran make a macth menggunakan media origami berkonteks tangram ini diharapkan mampu mengembangkan kemampuan komunikasi matematis peserta didik.

Penelitian dengan menggunakan konteks tangram pernah dilakukan oleh Ilma (2011) yang bertujuan untuk mengetahui gambaran kemampuan komunikasi matematis siswa pada saat proses pembelajaran materi bangun datar dengan menggunakan PMRI di kelas II B SDN 117 Palembang. Namun perbedaan dengan penelitian peneliti adalah penggunaan kreasi origami dan model pembelajaran make a match bertujuan agar kemampuan komunikasi matematis peserta didik lebih terlihat.

Dari uraian di atas, peneliti melakukan penelitian yang berjudul: "Desain Materi Bangun Datar Menggunakan Origami Berkonteks Tangram di SD Kelas II”. Penelitian ini bertujuan untuk menghasilkan learning trajectory menggunakan origami dan model pembelajaran make a match pada materi bangun datar dan mengembangkan kemampuan komunikasi matematis peserta didik pada materi bangun datar.

\section{METODE PENELITIAN}

\section{Jenis Penelitian}

Jenis penelitian ini menggunakan metode design research merupakan salah satu bentuk pendekatan kualitatif. Design research didefinisikan sebagai suatu kajian sistematis yang merancang, mengembangkan, dan mengevaluasi intervensi pendidikan (berupa program, strategi, bahan pembelajaran, produk dan sistem) sebagai solusi untuk memecahkan masalah yang kompleks dalam praktek pendidikan. Design research bertujuan untuk mengembangkan local instruction theory yang didasarkan pada teori yang sudah ada dan berdasarkan percobaan secara empirik melalui kerjasama antara peneliti dan guru yang bertujuan untuk meningkatkan relevansi penelitian dengan adanya kebijakan dan praktik pendidikan (Gravemeijer \& Cobb, 2006: 123). Design research merupakan penelitian pengembangan Development Research (Akker, et all., 2006: 4). Berbeda dengan 
Barab dan Squire (Akker, et all., 2006: 5) mendefinisikan design research sebagai suatu pendekatan yang bertujuan untuk membuat suatu teori baru, alat, praktik yang berguna dan secara potensial berdampak pada kegiatan belajar dan mengajar dalam latar yang natural. Design research dikembangkan sebagai suatu penelitian formatif yang menguji dan memperhalus desain pembelajaran (educational design) berdasarkan teori yang didapat dari penelitian sebelumnya. Oleh karena itu untuk mendapatkan hasil terbaik maka penelitian design research dilakukan dalam tiga siklus yang disesuaikan dengan tujuan penelitian

\section{Rancangan Penelitian}

Menurut Gravemeijer \& Cobb (2006: 28), terdapat tiga fase pelaksanaan design research yakni:

1. Persiapan eksperimen (preparing for the experiment)

Tahap persiapan eksperimen meliputi kegiatan mengklarifikasi tujuan pembelajaran (end points), menentukan langkah awal pembelajaran (starting points), dan menentukan teori pembelajaran lokal yang ingin dikembangkan (LIT/Local Instruction Theory).

2. Pelaksanaan uji coba/eksperimen desain (the design experiment) yang terdiri dari pilot experiment dan teaching experiment

Tahap pelaksanaan eksperimen meliputi suatu siklus pembuatan desain, eksperimen/implementasi desain, dan modifikasi desain berdasarkan temuan dari kegiatan eksperimen. Kelas pilot experiment merupakan kelas yang terdiri dari 6 orang peserta didik dengan kriteria dua orang berkemampuan tinggi, dua orang berkemampuan sedang, dan dua orang berkemampuan rendah berdasarkan hasil tes dan wawancara dengan guru kelas. Dimana peneliti berperan sebagai guru model dan guru kelasnya melihat apa yang dilakukan oleh peneliti untuk diterapkan pada kelas teaching experiment. Berbeda hal dengan kelas teaching experiment dimana guru kelas yang menjadi model dalam penelitian ini.

3. Analisis retrospektif (the retrospective analysis)

Tahap analisis retrospektif (retrospective analysis) adalah suatu kegiatan analisis terhadap desain yang telah diujicobakan dalam kegiatan sebelumnya berdasarkan data yang telah dikumpulkan dengan tujuan untuk mengembangkan desain tersebut

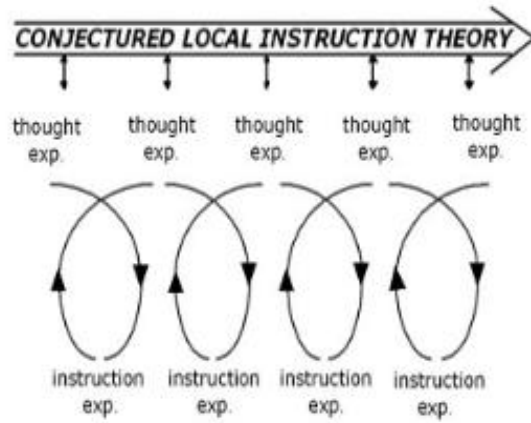

Gambar 3. Diagram Siklus Pelaksanaan Uji Coba/Eksperimen (Gravemeijer \& Cobb, 2006:28)

Seperti yang telah dikemukakan sebelumnya, dari diagram alir di atas terlihat bahwa pelaksanaan eksperimen dilakukan secara berulang-ulang dengan banyak siklus disesuaikan dengan tujuan pelaksanaan design research.

\section{Subjek Penelitian}

Subjek penelitian ini adalah seluruh peserta didik kelas II SD Negeri 43 Palembang. Peserta didik kelas IIA yang berjumlah 27 orang sebagai kelas teaching experiment dan kelas IIB berjumlah 6 orang sebagai kelas pilot experiment. Penelitian dilakukan pada tahun ajaran 2016/2017 semester genap.

\section{Teknik Pengumpulan Data}

Teknik pengumpulan data pada penelitian ini adalah wawancara, observasi yang terdiri dari observasi kelas dan kelompok, tes tertulis (pretest dan postest), dokumentasi (kamera video bersifat statis dan dinamis), dan catatan lapangan. 


\section{Teknik Analisis Data}

\section{Validitas}

Hypothetical Learning Trajectory (HLT)

Hypothetical Learning Trajectory yang berfungsi sebagai pedoman dalam menjawab rumusan masalah pada tahap analisa. Bertujuan untuk menghubungkan dan mengevaluasi konjektur yang sebenarnya dengan fakta yang dikumpulkan.

Pengambilan Kesimpulan

Proses pengambilan kesimpulan mengacu pada rekaman video, catatan lapangan, hasil observasi, dan hasil kerja peserta didik. Informasi tersebut memungkinkan pembaca untuk membangun penalaran dan mengarahkan argumen menuju suatu kesimpulan.

Trackability

Trackability adalah mengamati jalur proses pembelajaran. Data ini dapat digunakan untuk menjelaskan situasi dan temuan atau informasi secara detail sebagai suatu sebagai suatu alasan dalam memaparkan informasi atau kesimpulan.

\section{Reliabilitas}

Reliabel dalam penelitian kualitatif ini digunakan untuk menjaga konsistensi data. Reliabel kualitatif dilakukan dengan dua cara, yaitu:

Triangulasi data

Triangulasi data menggunakan sumber data untuk melihat keterkaitan antara sumber data yang diperoleh berupa catatan lapangan dan lembar observasi, wawancara, dokumentasi, dan rekaman video terhadap lintasan belajar. Kombinasi dari berbagai sumber data ini dipilih sebagai alat untuk diperiksa tingkat reliabelnya.

Interpretasi silang

Data pada penelitian membutuhkan pertimbangan dari para pakar yang ahli di bidang design research untuk memberikan saran mengenai data yang diperoleh berupa data video. Hal ini dilakukan untuk menghindari terjadinya subjektivitas dari peneliti dalam menginterprestasikan data hasil penelitian yang diperoleh di lapangan.

\section{HASIL PENELITIAN DAN PEMBAHASAN}

Hasil penelitian berupa Hypothetical Learning Trajectories yang terdiri dari tiga tahapan dan tiga aktivitas seperti gambar 4. Hypothetical Learning Trajectories (HLT) yang merupakan hipotesis mengenai trayek (alur lintasan) pembelajaran peserta didik dalam mempelajari suatu konsep matematika atau aktivitas mental peserta didik dalam mengonstruksi matematika. HLT yang telah diuji melalui kegiatan eksperimen dan direvisi melalui kegiatan analisis retrospektif dalam beberapa siklus (sesuai dengan tujuan penelitian) akan menghasilkan Local Instruction Theory (LIT). Dengan kata lain, HLT menjembatani pelaksanaan eksperimen dengan LIT.

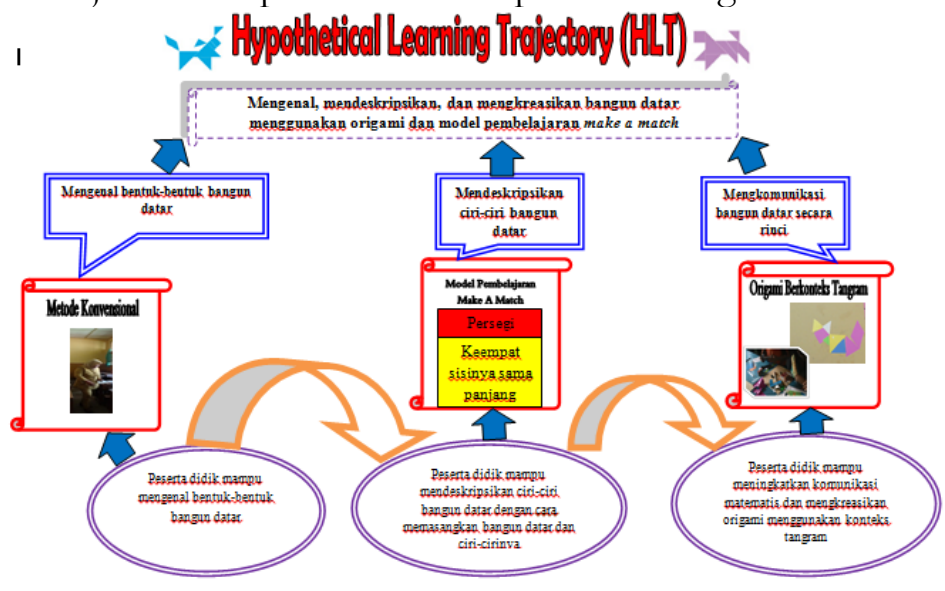

Gambar 4. HLT Bangun Datar 


\title{
The Preparing for Experiment:
}

Pada tahap ini, peserta didik diberikan pretest untuk mengukur kemampuan awal peserta didik dan adanya studi literatur pada tahap ini. Pada tahap pretest masih ada 5 orang peserta didik yang belum bisa menjawab soal pretest. hal ini menunjukkan peserta didik mengalami kesulitan dalam pengenalan ciri-ciri bangun datar.

\section{The Design Experiment: Pilot experiment dan teaching experiment}

Kegiatan pilot experiment dilakukan di kelas IIB SD Negeri 43 Palembang yang terdiri dari 6 orang peserta didik dengan 3 aktivitas. Sedangkan teaching experiment dilakukan di kelas IIA SD Negeri 43 Palembang yang terdiri dari 27 orang peserta didik. Pilot experiment dan teaching experiment bertujuan untuk mengetahui pengetahuan awal peserta didik dengan mengumpulkan data yang mendukung penyesuaian rencana lintasan belajar peserta didik sebelumnya.

\section{Aktivitas 1}

Guru menjelaskan materi bangun datar khususnya pada pengenalan bentuk-bentuk bangun datar dengan metode konvensional. Di awal peserta didik hanya berperan sebagai pendengar. Di sini peneliti hanya memperhatikan bagaimana cara guru menjelaskan dan bagaimana perhatian peserta didik. Setelah itu, peneliti membagikan LKS kepada 6 orang peserta didik dan mereka diminta mengisi LKS 1 yang bertujuan untuk mengetahui sejauh mana pengenalan mereka terhadap bentuk-bentuk bangun datar. Melalui aktivitas ini terlihat indikator kemampuan komunikasi matematis yaitu dapat memahami, menginterpretasikan dan menilai ide matematik yang disajikan dalam bentuk tulisan atau visual. Hal ini terlihat dari cara peserta didik mengerjakan LKS 1 dan berusaha menanyakan kepada guru hal terkait dengan bangun datar. Peserta didik tampak antusias memperhatikan penjelasan guru selama proses pembelajaran berlangsung. Setelah itu, peserta didik terlihat mampu memahami ide matematika yang ada dalam LKS 1 seperti gambar 5.

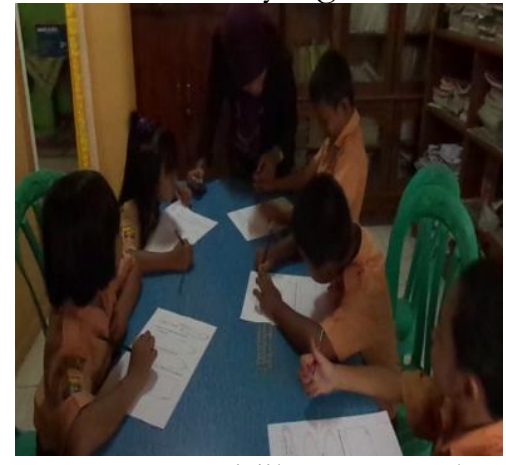

Gambar 5. Peserta Didik Mengerjakan LKS 1

\begin{abstract}
Aktivitas 2
Guru menggunakan model pembelajaran make a match untuk melatih pemahaman peserta didik tentang ciri-ciri bangun datar dengan memasangkan dan melakukan komunikasi matematis terhadap teman-teman yang lain dalam kelompoknya secara bergantian. Pada proses ini, peserta didik diharapkan dapat mendeskripsikan ciri-ciri bangun datar baik secara bahasa lisan maupun tertulis (dalam bentuk komunikasi matematis). Selanjutnya, peserta didik akan mengerjakan soal pada LKS 2 yang bertujuan untuk mengetahui pemahaman tentang ciri-ciri bangun datar. Pada aktivitas ini, terlihat kemampuan komunikasi matematis yaitu dapat menggunakan bahasa, notasi dan struktur matematik untuk menyajikan ide, dan menggambarkan hubungan pembuatan model. Hal ini terlihat pada saat peserta didik dalam mengerjakan soal pada LKS 2 dimana peserta didik mampu melukiskan gambar bangun datar sesuai dengan permintaan pada LKS tersebut seperti gambar 6 .
\end{abstract}




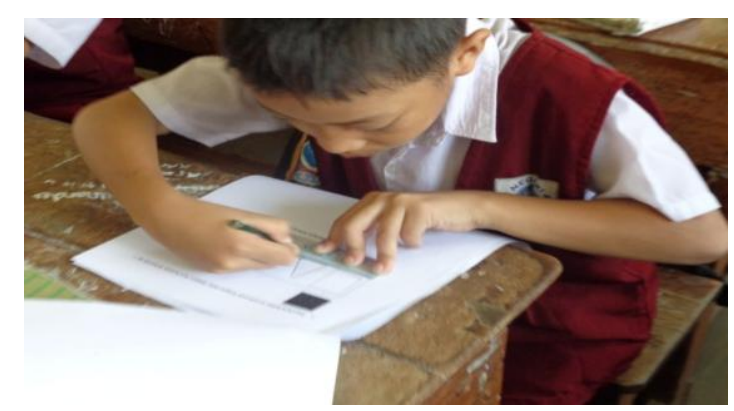

Gambar 6. Peserta Didik Menggambarkan Bangun Datar

\begin{abstract}
Aktivitas 3
Guru memberikan potongan origami berkonteks tangram (sudah dalam bentuk potongan) dan persegi (terbuat dari karton padi) serta lem. Peserta didik dalam kelompoknya akan melakukan komunikasi matematis dalam membentuk berbagai kreasi menggunakan origami berbentuk hewan, orang, benda, dan sebagainya. Kreasi origami yang dibuat oleh peserta didik menunjukkan bahwa peserta didik mampu menggunakan bahasa, notasi dan struktur matematik untuk menyajikan ide, dan menggambarkan hubungan pembuatan model Dilanjutkan dengan melukiskan pada kertas yang telah disediakan oleh guru. Penggunaan origami bertujuan untuk melatih kemampuan komunikasi matematis peserta didik. Setelah itu, diminta untuk mengerjakan LKS 3 yang terkait dengan origami yang akan menggiring kemampuan peserta didik dalam hal kemampuan komunikasi matematis. Langkah terakhir, peserta didik mampu mempresentasikan hasil kerjanya di depan kelas membuktikan bahwa peserta didik mampu mendeskripsikan bangun datar mulai dari ciri-ciri dan karakteristik setiap bangun datar. Saat peserta didik melakukan kerja kelompok menggunakan kreasi origami tampak hasil kreasi origami siswa yang beraneka ragam, seperti gambar berikut:
\end{abstract}
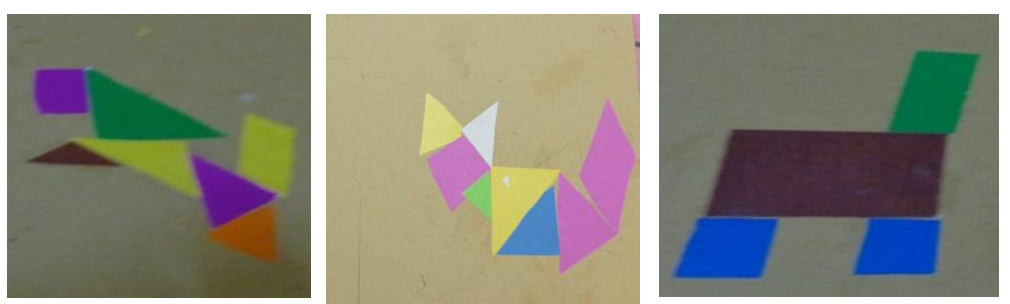

Gambar 7. Hasil Origami Menggunakan Konteks Tangram

Secara umum terlihat bahwa aktivitas belajar peserta didik meningkat. Terjadi perubahan aktivitas peserta didik yang biasanya pasif dan hanya mendengar menjadi aktif dalam pembelajaran, antusias dan bersemangat. Ini terlihat dari setiap tahapan aktivitas yang dikerjakan peserta didik. Peserta didik terlihat aktif dan kreatif selama proses pembelajaran berlangsung. Diawali dengan tahap awal berupa pengenalan bentuk bangun datar, dilanjutkan dengan kemampuan mengenal ciri-ciri bangun datar melalui model pembelajaran make a match dengan cara memasangkan kartu bangun datar dan ciri-ciri yang sesuai dengan bangun datar tersebut. Di akhiri dengan aktivitas menggunakan origami dan belajar membentuk berbagai kreasi berdasarkan konteks tangram. Hasil belajar peserta didik juga menunjukkan perubahan yang positif. Tahap awal peserta didik belum mampu menjawab pertanyaan pada pretest dengan baik, namun setelah dilakukan 3 kali aktivitas baik pada kelas pilot experiment dan teaching experiment terjadi peningkatan pada hasil posttest dari 27 orang peserta didik yang pada waktu pretest sulit menjawab pertanyaan. 


\section{PENUTUP}

Penelitian ini menghasilkan lintasan belajar berupa Hypothetical Learning Trajectory (HLT) bangun datar. Desain pembelajaran yang dilakukan menggunakan origami berkonteks tangram dengan pembelajaran make a macth ditujukan untuk meningkatkan kemampuan komunikasi matematis peserta didik. Pembelajaran selama penelitian dilakukan dalam serangkaian aktivitas. Pertama, peneliti dan guru model menggunakan model pembelajaran konvensional untuk memperkenalkan jenis-jenis bangun datar dilanjutkan dengan pengerjaan soal pada LKS 1 yang tersedia. Selanjutnya, peserta didik membuat kesimpulan pada LKS 1 tersebut. Melalui aktivitas peserta didik ini terlihat indikator kemampuan komunikasi matematis yaitu dapat memahami, menginterpretasikan dan menilai ide matematik yang disajikan dalam bentuk tulisan atau visual. Aktivitas kedua, menggunakan model pembelajaran make a match untuk melatih kemampuan peserta didik dalam memasangkan dan mendeskripsikan bangun datar menggunakan kartu. Melalui model pembelajaran ini, terlihat kemampuan komunikasi matematis yaitu dapat menggunakan bahasa, notasi dan struktur matematik untuk menyajikan ide, dan menggambarkan hubungan pembuatan model. Aktivitas terakhir adalah origami berkonteks tangram bertujuan untuk mengkreasikan berbagai bangun datar dengan konteks tangram menjadi bentuk yang variatif sekaligus mengetahui kemampuan komunikasi matematis peserta didik yaitu dapat menyatakan ide matematik dengan lisan, tulisan, mendemonstrasikan dan menggambarkan dalam bentuk visual. Pendesainan origami berkonteks tangram dan model pembelajaran make a match membantu memahami tentang materi bangun datar dan meningkatkan kemampuan komunikasi matematis peserta didik.

\section{DAFTAR PUSTAKA}

Akker, et all. 2006. Educational Design Research. New York: Routledge, pp: 3-7.

Althouse JK. 1997. Using Tangrams to Teach Geometry to Young Children. Early Childhood Education Journal. 24(4), pp: 239-243.

Gravemeijer, K \& Cobb, P. 2006. Design Research From A Learning Design Perspective, pp. 17-55.

Ilma, R.. 2011. Improving Mathematics Comunication Ability Of Students In Grade 2 Through PMRI Approach. Prociding International Seminar and the Fourth National Conference on Mathematics Education 2011 "Building the Nation Character through Humanistic Mathematics Education". Department of Mathematics Education, Yogyakarta State University, Yogyakarta, July 21-23 2011. [Online]. Tersedia : http://eprints.uny.ac.id/1371/1/P\%20-\%2054.pdf. [10 Februari 2013].

Kemendikbud. 2013. Silabus Mata Pelajaran Sekolah Dasar/Madrasah Ibtidaiyah (SD/MI). Jakarta: Kemendikbud.

Kriegler S. 1991. The Tangram: It's More than an Ancient Puzzle. Arithmetic Teacher 38(9), pp: 38-43.

National Council of Teacher's Mathematics. 2003. Developing geometry understandings and spatial skills through pu₹zlelike problems with tangrams: Tangram challenges. [Online]. Tersedia : www.nctm.org

Nurdin, E. (2016). Develop The Ability of Geometric Thinking in van Hiele Theory by Using Media Tangram. Proceeding of International Seminar on Teacher Education, pp : 743-748.

Sani, B \& Kurniasih, I. 2015. Ragam Pengembangan Model Pembelajaran Untuk. Meningkatkan Profesionalitas Guru. Jakarta: Kata Pena.

Sundayana, R. 2015. Media dan Alat Peraga dalam Pembelajaran Matematika. Bandung: Alfabeta. 